УДК 94(6):327+94(44):327

ББК 63.3(6)64-6+63.3(4Фра)64-6

\title{
Африканский капкан для Эммануэля Макрона
}

B.P. Филиппов

Институт Африки Российской академии наук (Москва, Россия)

\section{African Trap for Emmanuel Macron}

\author{
V.R. Filippov
}

Institute for African Studies of the Russian Academy of Sciences (Moscow, Russia)

Статья посвящена выяснению причин наращивания Францией военного присутствия в странах Тропической Африки. История африканской политики Пятой республики рассматривается в контексте энергетического кризиса, порожденного истощением запасов урановых руд на территории Франции. Специфика энергосистемы Французской республики состоит в несоразмерно высокой доле (около 75\%) электроэнергии, вырабатываемой на АЭС. Это обстоятельство обусловливает зависимость бывшей метрополии от закупок урановой руды в странах субсахарской Африки, бывших в прошлом колониями Французской империи. По мнению автора, в условиях обострения конкурентной борьбы за африканские минеральные ресурсы Франция может сохранить свои эксклюзивные права на закупку сахельского урана по демпинговым ценам, только наращивая свое военное присутствие в зоне Сахеля и Центральной Африке. Автор обосновывает вывод о том, что президент Э. Макрон столкнулся с почти неразрешимой проблемой: чем выше затраты на военные операции, тем дороже африканский уран для французских АЭС, тем меньше смысла в проведении дорогостоящей военной кампании на Черном континенте.

Ключевые слова: Франция, Эммануэль Макрон, операция «Бархан», энергетика Франции, Центральноафриканская Республика, Мали, Нигер, Чад, уран, «мягкая сила».

\section{DOI 10.14258/izvasu(2019)2-14}

Восьмой президент Пятой республики Эммануэль Макрон получил от своих предшественников обременительное африканское наследство, имя которому «Франсафрик». Этот военно-политический феномен с трудом поддается определению и однозначным интерпретациям. «Франсафрик» это сеть латентных связей, объединяющая в единый организм коррумпированные политические, финан-
The article is devoted to clarifying the reasons for France's increasing military presence in the countries of Tropical Africa. The history of African policy of the Fifth Republic is viewed in the context of the energy crisis, which is caused by the depletion of uranium ore reserves in France. The specifics of the power system of the French Republic are disproportionately high share (about 75\%) of electricity generated at nuclear power plants. This circumstance determines the dependence of the former metropolis on the purchase of uranium ore in the countries of sub-Saharan Africa, which were in the past colonies of the French empire. By the point of view of the author, France can retain its exclusive rights to purchase Sahel uranium at dumping prices only by increasing its military presence in the Sahel zone and in Central Africa, in an increasingly competitive climate for African mineral resources. The author substantiates the conclusion that President E. Macron is faced with an almost intractable problem: the higher the cost of military operations, the more expensive African uranium for French nuclear power plants, and thereafter the less sense in conducting an expensive military campaign on the Black Continent.

Key words: France, Emmanuel Macron, Operation «Barhan», power engineering of France, Central African Republic, Mali, Niger, Chad, uranium, «soft power».

совые, дипломатические и военные элиты Франции и африканских государств, это механизм, призванный обеспечивать реализацию французской неоколониальной стратегии в Африке.

Созданная Ш. де Голлем и существующая поныне «новая форма колониализма представляет собой явление до неприличия лицемерное, поскольку циничная эксплуатация прикрывается здесь насквозь 
фальшивой словесной эквилибристикой, и опасное, ввиду того, что противники названной системы истребляются безжалостно и без промедления, тогда как страдания эксплуатируемых народов умножаются стократ» [1, с. 47]. Поощряемая на государственном уровне коррупция, подкуп государственных деятелей, тайные криминальные сделки, трафик оружия, торговля наркотиками, отмывание денег, шантаж, политические убийства, разжигание родоплеменных конфликтов, массовые убийства населения, организация путчей и вооруженное вмешательство в дела африканских государств - все это обычный инструментарий системы «Франсафрик». Трудно даже перечислить все преступления, инспирированные Елисейским дворцом на Черном континенте за 74 года послевоенной истории.

Н. Саркози в ходе своей электоральной кампании говорил о его готовности отказаться от неприглядной практики «Франсафрик», переформатировать отношения Франции с африканскими странами, пересмотреть чересчур снисходительное отношение к злоупотреблениям ряда диктаторов. А затем последовали штурм президентского дворца Л. Гбагбо в Кот-д'Ивуаре и атаки французских «Рафалей» в Ливии. Позже Ф. Олланд, вступая в должность президента, объявил, что времена «Франсафрик» прошли, но вскоре случилась интервенция французской армии в Мали и война в ЦАР...

Э. Макрон вступил в должность 14 мая 2017 г., спустя всего четыре дня, 19 мая он был уже в Африке. Сам по себе этот факт свидетельствует об исключительной важности африканского вектора во внешней политике Франции. Двадцать пятый президент Французской республики прибыл в Республику Мали для встречи с солдатами и офицерами французского экспедиционного корпуса. Разумеется, в свите Э. Макрона был и президент Мали И.Б. Кейта, фактически назначенный на эту должность Елисейским дворцом. Встреча проходила в местечке Гао, где дислоцированы французские военные, задействованные в операции «Бархан» (эта кампания ведется с 1 августа 2014 г. и фактически является продолжением операции «Сервал».)

Отправка французских войск в зону Сахеля по официальной версии Елисейского дворца была обусловлена необходимостью борьбы с исламскими террористами в дружественных Парижу государствах этого региона и для защиты государственной целостности Республики Мали (напомню, племена туарегов провозгласили в 2012 г. суверенитет государства Азавад в обширной субсахарской зоне, в том числе и на северных территориях Мали). Эта версия, оправдывающая агрессию Франции «гуманитарными соображениями», была охотно принята союзниками Пятой республики по НАТО и поддерживалась масс-медиа «свободного мира». На са- мом же деле французские штыки были призваны удержать под эгидой Елисейского дворца богатейшие урановые рудники, которые десятилетиями эксплуатировались французским концерном «Арева» на дискриминационных для стран региона условиях. На сахельский уран все более явно претендовал Китай, готовый закупать уран по рыночным ценам, и вожди туарегских племен, стремящихся получить свою долю прибыли от рудников, расположенных на «их» территории. Кроме того, залежи урановых руд стали вожделенной целью Аль-Каиды Магриба и других исламистских группировок.

На закрытой встрече Э. Макрона с командованием экспедиционного корпуса обсуждалась сложная ситуация, в которой оказались французы в Сахеле [2]. Борьба с исламскими экстремистами не приносит ощутимого результата, государственное единство Мали до сих пор находится под вопросом, теракты в регионе приобрели систематический характер. И, тем не менее, завершая свой первый визит в зону боевых действий, президент объявил о намерении и дальше обеспечивать французское военное присутствие в регионе и продолжить операцию «Бархан». Этот визит был призван продемонстрировать приверженность Э. Макрона принципам африканской политики, проводимой его предшественниками, его намерение и дальше отстаивать интересы Пятой республики на территории Тропической Африки силой оружия.

2 июля 2017 г. Э. Макрон вновь прибыл в Мали для участия во встрече глав государств-членов региональной организации G5S. Она была создана по инициативе Парижа в 2015 г., а в 2017 г. была образована совместная военная группировка «пятерки». Уставная цель этой военно-политической структуры - борьба с терроризмом в регионе; сейчас она включает Нигер, Мали, Чад, БуркинаФасо и Мавританию. В Елисейском дворце тешат себя надеждой на то, что «государства-партнеры со временем приобретут способность обеспечивать свою собственную безопасность» [3]. Однако точнее было бы сказать, что эти государства, по мысли французов, захотят и будут способны отстаивать интересы Пятой республики в Тропической Африке. Как писала газета «Le Monde» накануне саммита G5S, «ставка Парижа очень велика: чем быстрее эта сила встанет на ноги, тем быстрее Елисейский дворец сможет, если не положить конец, то, по крайней мере, уменьшить формат операции «Бархан», которая стоит ему не менее 600 миллионов евро каждый год» [4].

По официальной версии июльский саммит был инициирован для того, чтобы «конкретизировать деятельность G5S». Эта расплывчатая формулировка должна была скрыть структурный кризис ассоциации: президент Чада И. Деби объявил, что готов 
выйти из проекта вследствие недостаточного финансирования. (На финансирование G5S в 2017-2022 гг. Франция выделила 42 млн евро, но этого не хватает для организации эффективных военных операций.) Э. Макрон понимает, что выход Республики Чад из состава «пятерки» поставит под угрозу успех операции «Бархан», как и то, что нищие государства Тропической Африки не могут самостоятельно финансировать крупные военные операции в регионе. Поэтому президент Франции не устает повторять, что французские солдаты в Сахеле защищают интересы всей Европы, что сил G5S даже при финансовой поддержке Франции недостаточно для победы над террористами, что Евросоюз и США также должны внести свою лепту в дело борьбы с исламским терроризмом. В июне 2017 г. Евросоюз нехотя выделил 50 млн евро на поддержку военных операций G5S [5], но, по мнению аналитиков, поддержание боеспособности «пятерки» требует в восемь раз большего объема финансирования.

В ноябре 2017 г. Э. Макрон отправился в большое африканское турне. За три дня он посетил три страны - Буркина-Фасо, Кот-д'Ивуар и Гану. Вояж проходил под флагом борьбы с терроризмом, однако его очевидной целью было укрепление пошатнувшихся позиций Пятой республики в странах Тропической Африки.

Накануне президент Франции объявил, что «хочет забыть о колониальном прошлом африканских стран и начать отношения с ними с чистого листа» $[6$, p. 3]. Однако в оценках серьезных экспертов звучал скепсис: «Широкое военное присутствие Франции в Сахеле, неослабевающие миграционные потоки и бюджетные проблемы... В Елисейском дворце осознают все трудности предстоящего визита на фоне спада влияния Франции и ее не везде положительного образа» [7].

Э. Макрон начал свое турне в Буркина-Фасо. Эта страна - самое слабое звено в цепи клиентелистских государств Франции в Африке. В начале ноября 2014 г. здесь был свергнут президент Б. Компаоре. Этот одиозный политик в октябре 1987 г. при поддержке французских спецслужб организовал путч и санкционировал убийство любимого народом президента-реформатора Т. Санкары. За это он был обласкан Елисейским дворцом и назван «ближайшим другом Франции» в Западной Африке. Когда над головой Б. Компаоре нависла угроза суда, он был вывезен французским спецназом за пределы страны. В Буркина-Фасо, где до сей поры чтут убитого президента, его последователи представляют собой серьезную политическую силу.

Э. Макрон, полагаясь на опыт политической демагогии, надеялся завоевать симпатии граждан этой страны. Однако его ожидало горькое разочарование: визит сопровождался митингами и пикетами: молодые буркинабе требовали вывести с территории своей страны французские войска и забросали машину Э. Макрона камнями. Под окнами университета Уагадугу, в котором французский президент встречался со студентами, митингующие скандировали: «Долой империализм», «Французские войска - из Буркина-Фасо», «Нет французским базам в Африке» [8]. Студенты задавали Э. Макрону «неудобные» вопросы, например, почему так мало африканцев учится во Франции и так много французских солдат размещены в Африке. Во время дебатов молодые люди говорили о том, что Франция «несет ответственность за убийство Муаммара Каддафи», a «присутствие французских солдат в Сахеле - это новая колонизация» $[9$, p. 8].

Встреча со студентами показала, что молодые буркенийцы не склонны верить уверениям в любви и стремлении к обоюдовыгодному сотрудничеству. Они хотят устранить из практики франко-африканских отношений все то, что несет печать неоколониализма: разграбление природных ресурсов африканских стран, зависимость франка КФА от курса евро, поддержку одиозных африканских диктаторов и, главное, присутствие французских войск на территории африканских стран [6, р. 5].

На следующий день, 29 ноября, Э. Макрон был уже в Абиджане, где принимал участие в Пятом саммите Европейского и Африканского союзов [10]. Кот-д'Ивуар всегда был форпостом Франции в Тропической Африке, и в этой стране Э. Макрон чувствовал себя намного более комфортно, нежели в Буркина-Фасо. Однако и здесь его ожидали досадные неожиданности. Э. Макрона встречал в Международном аэропорту Абиджана не президент Кот-д'Ивуара А. Уаттара, а вице-президент этой страны Д. Каблан Дункан [11]. В то же время А. Уаттара лично приветствовал в аэропорту Т. Мбасого, президента Республики Экваториальная Гвинея. Журналисты сочли это реваншем: ранее в Париже президента Кот-д'Ивуара встречал лишь министр французского правительства.

Главной темой саммита стала работорговля в Ливии. Президент Франции в этом контексте предложил «африкано-европейскую инициативу» для борьбы с экстремистскими группами, угнетающими мигрантов в Ливии. Он декларировал, что операция в Ливии должна обеспечить эвакуацию тех, то подвергается гонениям в регионе исхода мигрантов, и заявил о своей готовности ускорить развертывание воинского контингента G5S. Позже Э. Макрон анонсировал проведение спецоперации в Ливии, направленной на демонтаж сетей экстремистов [12]. Однако эти планы так и остались нереализованными. Не было определено, какие страны и в какой форме будут принимать участие в военных акциях. Корреспондент портала Jeune Afrique В. Духем кон- 
статировал: «Как это часто бывает на представительных международных форумах, выступления, полные добрых намерений, редко сопровождаются реальными действиями» [13].

В ходе саммита Э. Макрон провел три двусторонние встречи. Журналисты отметили его чрезвычайно дружеские объятия с президентом Габона Али бен Бонго Ондимбой. Напомним, что этот политик пришел к власти в 2009 г. после смерти отца, О. Бонго, в результате не вполне прозрачных выборов. О. Бонго был самым ярким представителем системы коррупционных связей между политическими, экономичес-кими и военными элитами Франции и франкоговорящих африканских стран. В кулуаpax Елисейского дворца говорили, что во Франции не может стать министром по делам Франкофонии человек, которого невзлюбил О. Бонго. Секрет его могущества прост: Франции очень нужны габонская нефть и габонский уран. Сам О. Бонго сформулировал это так: «Габон без Франции — как автомобиль без водителя. Франция без Габона - как автомобиль без топлива...» [14].

В 2016 г. А. Бонго вновь «одержал победу» на выборах, но на сей раз их чистота вызвала сомнения не только в Африке, но и в Европе. Представители ЕС потребовали провести пересчет голосов, что фактически означало признание выборов нелегитимными. Особенно болезненно воспринял А. Бонго позицию Франции, которая настаивала на проведении ревизии. Э. Макрон решил пренебречь такой мелочью, как легитимность. Очевидно, что энергетический голод Франции толкает французского президента в объятия президента Габона, несмотря на серьезные сомнения в его политической чистоплотности.

Был отмечен также «высокий, братский уровень отношений, объединяющих короля Марокко Мохаммеда VI и президента Франции Эммануэля Макрона» [15]. Главы двух государств долго беседовали в резиденции Мохаммеда VI в Абиджане, речь шла о борьбе с терроризмом и миграционных процессах в Африке. Именно на Марокко сделает ставку Елисейский дворец, стремящийся превратить страны Магриба в своеобразный буфер, призванный защитить Европу от наплыва мигрантов из Африки.

В Абиджане состоялась короткая встреча Э. Макрона с президентом Того Ф. Гнассингбой. Полстолетия семейной диктатуры отца и сына Гнассингбе вызывает сейчас не только недовольство оппозиции, но и раздражение Парижа [16]. Президент Франции дал понять тоголезскому коллеге, что тот должен уйти в ходе следующих выборов.

Э. Макрон завершил африканское турне в Республике Гана. Он встретился с президентом Наной Акуфо-Аддо и вновь обратился к африканской молодежи. Но главным событием этого визита стала речь Н. Акуфо-Аддо, который «выступил за независимую Африку, а не Африку, ищущую благотворительности»; он осудил то, что «можно назвать попрошайничеством африканцев во Франции». Отвечая на вопрос ганского журналиста о том, будет ли Франция наращивать «поддержку» африканских стран за пределами своих бывших колоний, ганский лидер сказал: «Мы не можем основывать политику в наших странах, в наших регионах, на нашем континенте на поддержке, которую хотел бы оказать нам Западный мир, Франция или ЕС. Это не работало вчера и не будет работать завтра». Он призвал избавиться от менталитета зависимости, «от менталитета, который заставляет задаваться вопросом о том, что Франция может сделать для нас. Франция должна делать то, что она захочет делать для своей же пользы, если это совпадает с нашими интересами» [17].

Ганские масс-медиа отметили, что выступление Н. Акуфо-Аддо «очевидно, смутило Макрона, который не знал, в какой угол комнаты смотреть и был заметно взволнован» [17]. Журналисты провозгласили президента Ганы новым рупором Африки, лидером, который способен покончить с французским неоколониализмом. Что касается выступления Э. Макрона в Аккре, то оно не отличалось оригинальностью и было фактически повторением уже сказанного в Уагадугу. Суть дискурса сводилась к следующему: «Если Африка не сможет успешно развиваться, то и Европа потерпит неудачу в своем развитии, будучи дестабилизирована волнами мигрантов» [18, p. 5].

Наиболее интересным сюжетом на встрече президентов в Гане стал тоголезский кризис [7]. Стало ясно, что Париж вовсе не поддерживает требование оппозиции о немедленной отставке тоголезского диктатора. Елисейский дворец до отстранения узурпатора от власти хотел бы добиться от тоголезской оппозиции гарантий на неоспоримые торговые преференции. Э. Макрон предложил Н. Акуфо-Аддо роль посредника между узурпатором, оппозицией и Елисейским дворцом. Известно, что президент Ганы не готов защищать «максималистскую» позицию и попросить Ф. Гнассингбе незамедлительно отказаться от президентства. Именно поэтому Э. Макрон и избрал его на роль медиатора в переговорах по урегулированию политического кризиса в Того.

Нет никаких оснований оценивать итоги африканского турне Э. Макрона как успех французской дипломатии. Высокомерный тон выступлений и амбициозность президента Франции возмутили африканскую аудиторию. В итоге журналисты констатировали, что «африканская молодежь относится все более враждебно к присутствию Франции на континенте» $[6$, p. 4]. Уверения в том, что отныне 
Елисейский дворец будет разговаривать со странами Черного континента на равных, вызывают лишь скепсис и недоверие.

Не принес успехов президенту Пятой республики и 2018 г. На сей раз «камнем преткновения» стала ситуация в Центральноафриканской республике. Напомню: в начале нынешнего столетия противостояние прозелитов христианства и приверженцев ислама в Центральноафриканской республике привело эту страну к кровопролитной гражданской войне. Уже тогда непредвзятым наблюдателям было очевидно, что «за непрекращающимися кризисами, которые парализуют ЦАР, стоит Франция» [19]. Бывшая метрополия стремилась восстановить свой контроль над богатыми залежами урана, алмазными копями и золотоносными приисками.

К сентябрю 2013 г. государство в ЦАР было полностью парализовано. В ситуации «управляемого хаоса» в Елисейском дворце было решено заявить о своих правах на бывшую колонию: была инициирована воинская операция, получившая название «Сангарис». В операции в разное время принимали участие 15 тыс. военных, в наиболее сложные моменты в ЦАР воевали около 2 тыс. чел. За три года французам удалось несколько стабилизировать ситуацию, однако в октябре 2016 г. Ф. Олланд принял решение завершить операцию, оставив в Центральной Африке лишь небольшой воинский контингент. Это было вынужденное решение: на операцию в Центральной Африке было израсходовано 500 млн евро, для французской казны эта нагрузка оказалась чрезмерной. Кроме того, Елисейский дворец оказался в двусмысленном положении: в Сахеле французские солдаты воюют, якобы, с исламскими террористами (операция «Бархан»), а в ЦАР французы фактически встали на сторону исламских экстремистов из группировки «Селека». Так или иначе, операция «Сангарис» была приостановлена, не принеся Пятой республике ни воинской славы, ни заметных политических или экономических дивидендов. Достичь мира в этой истерзанной войной стране не получилось, кровопролитие продолжалось. Президент К. СамбаПанза, занявшая этот пост благодаря французским штыкам, не смогла установить контроль над большей частью территории ЦАР и добиться масштабной поддержки соотечественников.

На президентских выборах 2016 г. победу одержал Ф.-А. Туадера. Это опять-таки «был в значительной мере проект международных спонсоров ЦАР, прежде всего, Франции» [20]. Первые годы президентства Ф.-А. Туадеры трудно назвать успешными. Правительственным войскам удалось взять под контроль лишь 10 из 16 префектур; 80\% территории контролировались вооруженными группировками (до сих пор в ЦАР действуют 17 вооруженных груп- пировок). Христиане и мусульмане, разведенные миротворцами ООН, теперь продолжали родоплеменную резню внутри каждой из враждующих конфессиональных общностей. Полмиллиона граждан ЦАР укрываются в лагерях беженцев. Экономика страны разваливалась, ВВП упал еще на $36 \%$, привлечение иностранных инвестиций так и осталось предвыборным обещанием. Государственный аппарат деградировал, коррупция превратилась в национальную проблему.

Все это заставило Ф.-А. Туадеру резко изменить внешнеполитические ориентации. Убедившись в неспособности Франции обеспечить эффективную помощь его правительству, он неожиданно обратился за поддержкой к России. В октябре 2017 г. состоялась встреча Ф.-А. Туадеры с министром иностранных дел РФ С. Лавровым. Достигнутые договоренности касались сотрудничества в сфере добывающей промышленности и военной помощи ЦАР со стороны РФ. В результате этой встречи в декабре 2017 г. было подписано военное соглашение между Москвой и Банги. 23 мая 2018 г. президент Ф.-А. Туадера встретился с президентом РФ В. Путиным на полях Петербургского экономического форума. После этого правительства России и ЦАР подписали ряд двусторонних соглашений, но «каково их содержание и каким вопросам они посвящены» [21], осталось тайной. Вскоре МИД РФ инициировал решение Совбеза ООН, позволившее России поставить в ЦАР крупную партию стрелкового оружия [22].

26 января 2018 г. российский военный борт совершил посадку в аэропорту Банги. МИД РФ объявил, что «на нужды центральноафриканской армии... поставлена партия стрелкового вооружения и боеприпасов... и командированы 5 военных и 170 российских гражданских инструкторов для подготовки военнослужащих ЦАР» [23]. Пять военных это кадровые разведчики ГРУ, а «гражданские специалисты» - это бойцы частной военной компании «Группа Вагнера». В апреле появилась информация о том, что всего в страну прибыли 1,4 тыс. российских военных специалистов, среди них офицеры психологической войны, которые незамедлительно развернули антифранцузскую пропаганду [24]. Служба безопасности президента была полностью укомплектована российскими специалистами, которые быстро заняли место руандийских военнослужащих из миссии ООН. Вскоре состоялось торжественная церемония по поводу завершения подготовки российскими инструкторами первых 200 чел. для правительственных вооруженных сил. Парад принимал президент страны. Советником Ф.-А. Туадеры по безопасности был назначен некто В. Захаров. Влияние этого человека теперь, якобы, так велико, что «ни одно сколько-нибудь значимое решение не принимается без его участия» [25]. 
Одновременно российские предприниматели приступили к освоению природных богатств Центральной Африки. По некоторым данным отечественные и китайские частные компании при политической поддержке Москвы и Пекина под защитой российских военных начали добычу алмазов в Бриа и в районе Берберати. Южнее Банги неназванные российские компании ведут заготовку ценной африканской древесины. Многолетнее доминирование Пятой республики в ЦАР теперь поставлено под сомнение, «в Париже видят, что его влияние... ослабло до тоненького ручейка» [26]. Французские масс-медиа адресуют хозяину Елисейского дворца вопрос: «почему в этой объятой хаосом стране, прежде находившейся в зоне влияния Франции, теперь столь очевидно военное присутствие России?» [27].

Э. Макрон очень хотел бы войти в историю как государственный деятель, способный отказаться от использования армии в борьбе за влияние в Тропической Африке и основывающий свои отношения с африканскими странами лишь на использовании ресурсов «мягкой силы». Но геополитические и макроэкономические реалии таковы, что надеждам этим не суждено оправдаться. Над Э. Макроном довлеет урановый императив.

Дело в том, что ядерная энергетика для Франции имеет определяющее значение: АЭС производят около 480 ТВт, т.е. $75 \%$ всей вырабатываемой в стране электроэнергии. Вплоть до конца ХХ столетия Франция была крупнейшим производителем урана в Западной Европе: суммарные мощности 20 месторождений урановой руды достигали 4 тыс. т в год, корпорация «COGEMA» обеспечивала около 75\% производства необходимого объема уранового топлива. Но в начале нынешнего столетия собственные ресурсы урановой руды во Франции закончились. Теперь обеспечение французской ядерной энергетики урановым топливом осуществляется в основном за счет поставок из стран Тропической и Центральной Африки. Однако здесь в последнее десятилетие все большую угрозу интересам Франции представляет появление новых игроков на африканских рынках урана. Французские компании не смогут долго удерживать под своим контролем добычу этого ценного сырья в Африке. Это побудило Национальное собрание одобрить закон, предписывающий снижение доли электроэнергии, получаемой на АЭС, до 50 \%. 28 ноября 2018 г. Э. Макрон анонсировал Программу развития энергетического сектора Франции на ближайшие десять лет, которая предусматривает отключение 14 атомных реакторов к 2035 г. Но это планы на отдаленное будущее. А пока утрата контроля над урановыми рудниками Сахеля чревата для Пятой республики коллапсом экономики. Атомная энергетика основа конкурентоспособности страны. Уже сейчас цена электроэнергии в промышленном секторе экономики Франции значительно выше, чем аналогичный показатель в Германии (46 vs 36 евро за мегаватт-час).

Борьба за эксклюзивные права на добычу и закупки урановой руды по демпинговым ценам требует от Пятой республики масштабных инвестиций. Елисейский дворец вынужден тратить огромные деньги на «миротворческие» операции в регионе, цель которых - защита марионеточных политических лидеров от «внутренних врагов», от контрэлит и сепаратистов, которые тоже желают участвовать в перераспределении доходов от природной ренты. Бывшая метрополия вынуждена оплачивать вооружение и обучение армий африканских стран. До недавнего времени эти расходы восполнялись за счет крайне низких закупочных цен на руду. Но теперь у Пятой республики появились серьезные конкуренты, готовые закупать урановую руду по рыночным ценам, а африканские правители в ситуации выбора становятся все более разборчивыми.

Политические и экономические реалии таковы, что Пятая республика вынуждена будет сохранять и, возможно, наращивать свое военное присутствие в субсахарской зоне. Понятно желание Э. Макрона «таскать каштаны из огня» руками своих союзников по НАТО и африканских государств - сателлитов Франции, входящих в альянс G5S. Но и те, и другие прекрасно понимают, что Пятая республика стремится решать собственные проблемы за их счет. Белый дом вполне устраивает то, что роль жандарма в Тропической Африке взяла на себя Франция. Что касается Германии, то ее военное присутствие в Сахеле мотивировано в основном желанием организовать кордон, препятствующий неконтролируемой миграции в Западную Европу. Африканские же государства G5S (их граждане в большинстве своем исповедуют ислам) не слишком охотно участвуют в боевых действиях: население симпатизирует скорее исламистам, чем французским «миротворцам», а властные элиты стремятся извлечь из участия в контролируемом Францией альянсе лишь материальную и политическую выгоду.

Для Э. Макрона на большой африканской шахматной доске сложилась патовая ситуация. Чем выше затраты на военные операции, тем дороже африканский уран для французских АЭС, тем меньше смысла в проведении этой дорогостоящей военной кампании. 


\section{Библиографический список}

1. Васильев А.П. Генерал де Голль и крушение Французской Империи // Национальные интересы. 1999. № 2 (3).

2. Barluet A. Au Sahel, l'opération «Barkhane» face aux limites de son action. URL: http://www.lefigaro.fr/international/2018/02/11/01003-20180211ARTFIG00137-va-t-onvers-la-fin-de-l-operation-barkhane-au-sahel.php.

3. Opération Barkhane. URL: https://www.defense. gouv.fr/operations/operations/sahel/dossier-de-presentation-de-l-operation-barkhane/operation-barkhane.

4. Hofnung T. Macron et le Sahel, cest par où la sortie? URL: https://www.lemonde.fr/afrique/article/2017/06/30/ macron-et-le-sahel-c-est-par-ou-la-sortie_5153480_3212.html.

5. EU commits $50 \mathrm{mln}$ euros to combat militants in West Africa. URL: https://af.reuters.com/article/nigeriaNews/ idAFL8N1J24LK.

6. Burkina Faso. Une grenade pour l'arrivée de Macron à Ouagadougou // Le journal numérique. 2017. 28 novembre.

7. Berthemet T. Macron à la conquête des Africains. URL: http://inosmi.ru/politic/20171129/240879879.html.

8. Macron Publicly 'Humiliates' Burkina Faso President as French Leader's Africa Trip Goes Wrong. URL: https://on.rt. com/8tb9.

9. Ce qu'il faut retenir du discours de Macron au Burkina Faso // Le Figaro. 2017. 28 novembre.

10. Ouverture du Sommet UA-UE à Abidjan ce mercredi. URL: http://www.rfi.fr/afrique/20171129-ouverture-sommet-ue-ua-abidjan-mercredi.

11. Arrivée du président Macron à Abidjan. URL: http:// www.sommetuaue2017.ci/arrivee-du-president-macronsommet-ua-ue-abidjan-2017/.

12. Sommet UA-UE : Macron annonce une opération pour démanteler les réseaux de trafiquants de migrants en Libye. URL: http://tchadinfos.com/afrique/sommet-ua-ue-macronannonce-une-operation-pour-demanteler-les-reseaux-de-trafiquants-de-migrants-en-libye/.

13. Duhem V. Sommet UA-UE : demandez le programme! URL: http://www.jeuneafrique.com/497581/politique/sommet-ua-ue-demandez-le-programme/.

14. Gabon President Omar Bongo Ondimba Dies. URL: http://www.thetimes.co.uk/tto/news/. 15. Alaoui M.C. Sommet UA-UE: le roi Mohammed vi reçoit Emmanuel Mmacron et le president de l'Angola. URL: http://fr.le360.ma/politique/ sommet-ua-ue-le-roi-mohammed-vi-recoit-emmanuelmacron-et-le-president-de-langola-145169.

16. Les Togolais doivent pouvoir «s'exprimer librement», estime le président français. URL: http://www.lemonde. $\mathrm{fr} /$ afrique/article/2017/11/30/emmanuel-macron-souhaite-que-les-togolais-puissent-s-exprimer-librement_5222740_3212.html\#iLD3WoQh2VsscfER.99.

17. Macron au Ghana : le discours mémorable du président ghanéen sur l'autonomie africaine viral sur les réseaux sociaux // Fr.africanews. URL: http://frafricanews. com/2017/12/06/macron-au-ghana-le-discours-memorabledu-president-ghaneen-sur-l-autonomie/.

18. Bensimon C. Au Ghana, Macron réitère son message aux jeunes Africains pour qu'ils restent et réussissent en Afrique // Le monde. 2017. 30 november.

19. CENTRAFRIQUE: assassinat de trois journalistes russes: un jeu de la France? URL: http://palmarescentrafrique. com/centrafrique-assassinat-de-trois-journalistes-russes-unjeu-de-la-france/.

20. Кусов В.Г. Фостен-Арканж Туадера // Правители Африки: XXI век. URL: https://africanrulers.ru/main/ biographies/centralafrica_touadera/.

21. Vinograd C. There's a New Battle for Influence in Central Africa, and Russia Appears to Be Winning. URL: https:// www.washingtonpost.com/news/worldviews/wp/2018/05/31/ theres-a-new-battle-for-influence-in-central-africa-andrussia-appears-to-be-winning/? noredirect=on\&utm_ term $=.97 \mathrm{a} 50 \mathrm{c} 7 \mathrm{c} 1590$.

22. Ourdan R. Soldats, mercenaires et conseillers russes se multiplient dans la capitale centrafricaine. URL: https:// www.lemonde.fr/afrique/article/2018/04/23/la-russie-installe-peu-a-peu-sa-presence-dans-la-capitale-centrafricaine_5289462_3212.html.

23. Kirilenko A. Blood Diamonds. Who Killed Russian Journalists in the CAR, and What Do Putin's Chef and St Petersburg Police Have to Do with It? URL: https://theins. $\mathrm{ru} /$ uncategorized/114123?lang=en.

24. Signer D. Wie Russland afrikanische Krisenländer infiltriert. URL: https:/www.nzz.ch/international/wie-russland-afrikanische-krisenlaender-infiltriert-ld.1389297.

25. Нелюбин Е. Президент ЦАР доверил свою безопасность россиянам. URL: https://www.bfm.ru/news/391294.

26. Dietrich T. En Centrafrique, un parfum de guerre froide. URL: https://www.lopinion.fr/edition/international/ en-centrafrique-parfum-guerre-froide- 156731.

27. Bouessel Ch., Sari E. Pourquoi Vladimir Poutine avance ses pions en Centrafrique. URL: https://www.nouvelobs.com/monde/20180504.OBS6191/pourquoi-vladimirpoutine-avance-ses-pions-en-centrafrique.html. 